\title{
Elegía inconclusa
}

Oh tú, a quien le fuera otorgada esa innombrable lealtad de los cielos

que nosotros llamamos infancia: no permitas

que el destino la revoque y cancele. Incluso el prisionero

que tenebrosamente se pudre y se pierde en la celda

es asistido por ella en secreto hasta el fin. Porque, intemporal,

sostiene al corazón. Y aún al enfermo, cuando mira con fijeza - absorto-y comprende,

y la habitación ya no le da más respuesta (pues la habitación es algo curable,

como también son curables aún las cosas, sus cosas, esas mismas que yacen en derredor $y$, febriles, participan en su enfermedad...-

también a éste, incurable, desahuciado, perdido, le rinde sus frutos. Porque la infancia conserva con intacta pureza

su almácigo cordial en la naturaleza ya decaída.

$\mathrm{Y}$ no es que fuera inofensiva, no. El error embellecedor que la engalana y adorna

sólo pasajeramente puede engañarnos. No está más en seguridad que nosotros, ni en modo alguno más protegida. Ninguna deidad equilibra y anula su peso.

Se halla indefensa como nosotros, desprotegida como los animales en el invierno.

Y más indefensa aún, pues nada sabe de escondrijos ni de resguardos.

Desprotegida como si ella misma fuera lo amenazante.

Indefensa como un incendio, como un gigante, como un veneno,

como algo que rondara de noche en la casa aquella que nos mueve a inquietud y sospecha,

la de la puerta con el cerrojo pasado.

Porque, ¿quién no comprendería que mienten las manos de la protección y el amparo, 
y que ellas mismas - las protectoras- se hallan amenazadas también? ¿Quién, pues, puede brindar protección?

- ¡Yo!

- ¿Quién?

- Yo, la madre. Yo puedo. Yo fui antemundo.

A mí me ha confiado la Tierra cómo procede con la semilla para que germine salva y entera. ¡Oh noches de confidencia en que ambas,

la Tierra y yo, llovimos serenamente, de un modo abrileño, en nuestro propio regazo!

Ay, ¿quién te podría mostrar - oh varón- la fecunda concordia

en que nos sentimos una a la otra? A ti jamás te será revelada la serenidad del universo en ese preciso momento en que ella se cierra

alrededor de un crecimiento.

Generosidad de las madres. Voces de quienes aquietan y calman. ¡Y sin embargo...!

Eso mismo que nombras ahora es el peligro, es todo el puro riesgo del mundo-

y al sentirlo tú plenamente, se invierte y se torna en resguardo.

La infancia cordial se mantiene en medio de eso como si ella misma fuera su centro:

agotando $\sin$ temor el temor que hay en ello.

¡Pero la angustia...! Se aprende de una sola vez y de pronto en ese toque final que aporta la naturaleza humana y que, por serlo, no está herméticamente sellada. Como una corriente de aire,

la angustia se cuela por entre sus resquicios y hendiduras. Y ahí está. Sopla

por encima de las espaldas del niño absorto en sus juegos y silba viperina introduciendo la división en la sangre: la rápida sospecha

de que, más tarde, siempre será comprensible sólo una parte de la existencia, siempre no más que un fragmento, o cinco fragmentos cualesquiera, ni siquiera capaces de relacionarse entre sí 
o de unirse de alguna manera, y todos quebradizos y frágiles.

$\mathrm{Y}$ ya divide, en la espina dorsal, el delgado tallo de la voluntad

para que, ramificado, no sea sino un brazo del árbol de Judas de la elección

y, dudando, se transforme en seca y dura madera al crecer...

Berg am Irchel, diciembre, 1920 